
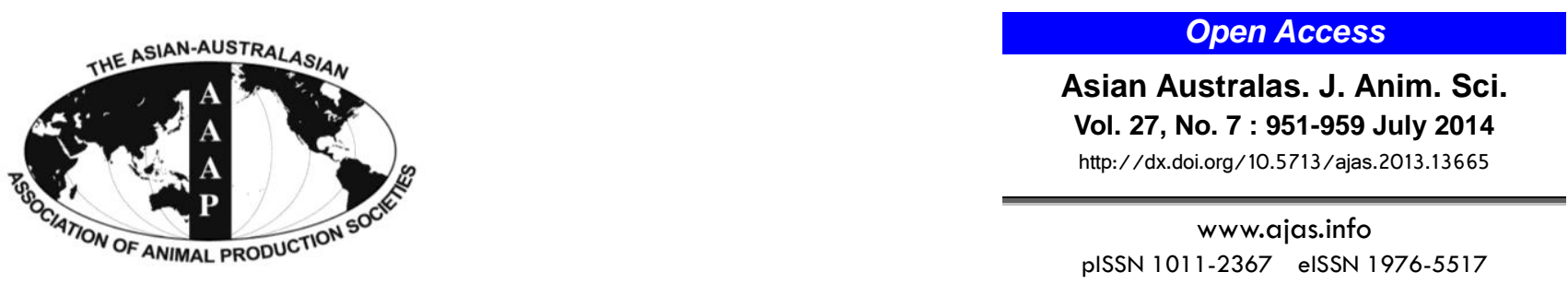

\title{
Effects of Linseed Oil or Whole Linseed Supplementation on Performance and Milk Fatty Acid Composition of Lactating Dairy Cows
}

\author{
Wisitiporn Suksombat*, Lam Phuoc Thanh ${ }^{1}$, Chayapol Meeprom, and Rattakorn Mirattanaphrai \\ School of Animal Production Technology, Institute of Agricultural Technology, \\ Suranaree University of Technology, Nakhon Ratchasima, 30000, Thailand
}

\begin{abstract}
The objective of this study was to determine the effects of linseed oil or whole linseed supplementation on performance and milk fatty acid composition of lactating dairy cows. Thirty six Holstein Friesian crossbred lactating dairy cows were blocked by milking days first and then stratified random balanced for milk yields and body weight into three groups of 12 cows each. The treatments consisted of basal ration (53:47; forage:concentrate ratio, on a dry matter [DM] basis, respectively) supplemented with 300 $\mathrm{g} / \mathrm{d}$ of palm oil as a positive control diet (PO), or supplemented with $300 \mathrm{~g} / \mathrm{d}$ of linseed oil (LSO), or supplemented with $688 \mathrm{~g} / \mathrm{d}$ of topdressed whole linseed (WLS). All cows were received ad libitum grass silage and individually fed according to the treatments. The experiment lasted for 10 weeks including the first 2 weeks as the adjustment period, followed by 8 weeks of measurement period. The results showed that LSO and WLS supplementation had no effects on total dry matter intake, milk yield, milk composition, and live weight change; however, the animals fed WLS had higher crude protein (CP) intake than those fed PO and LSO ( $<<0.05)$. To compare with the control diet, dairy cow's diets supplemented with LSO and WLS significantly increased milk concentrations of cis-9,trans-11conjugated linoleic acid (CLA) ( $\mathrm{p}<0.05$ ) and $\mathrm{n}-3$ fatty acids (FA) ( $\mathrm{p}<0.01$ ), particularly, cis-9,12,15-C18:3, C20:5n-3 and C22:6n-3. Supplementing LSO and WLS induced a reduction of medium chain FA, especially, C12:0-C16:0 FA $(\mathrm{p}<0.05)$ while increasing the concentration of milk unsaturated fatty acids (UFA) $(\mathrm{p}<0.05)$. Milk FA proportions of $\mathrm{n}-3$ FA remarkably increased whereas the ratio of $\mathrm{n}-6$ to $\mathrm{n}-3$ decreased in the cows supplemented with WLS as compared with those fed the control diet and LSO $(\mathrm{p}<0.01)$. In conclusion, supplementing dairy cows' diet based on grass silage with WLS had no effect on milk yield and milk composition; however, trans-9C18:1, cis-9,trans-11-CLA, n-3 FA and UFA were increased while saturated FA were decreased by WLS supplementation. Therefore, it is recommended that the addition $300 \mathrm{~g} / \mathrm{d}$ of oil from whole linseed should be used to lactating dairy cows' diets. (Key Words: Linseed Oil, Whole Linseed, Milk Production, Milk Composition, Milk Fatty Acids, Dairy Cows)
\end{abstract}

\section{INTRODUCTION}

The inclusion of saturated fats of animal origin in human diets may increase the risk for cardiovascular diseases (Joyce et al., 2009). It has been estimated that dairy products contribute up to $60 \%$ of saturated fatty acids (SFA) to human diets in some European countries (Chilliard et al., 2007). Furthermore, dietary oilseed supplements generally increase the concentration of trans fatty acids (FA) in

\footnotetext{
* Corresponding Author: Wisitiporn Suksombat. Tel: +66-44224152, Fax: +66-44-224150, E-mail: wisitpor@sut.ac.th

${ }^{1}$ Department of Animal Sciences, College of Agriculture and Applied Biology, Can Tho University, Can Tho, 10000, Viet Nam. Submitted Oct. 22, 2013; Revised Jan. 15, 2014; Accepted Feb. 18, 2014
}

bovine milk (Glasser et al., 2008), which, depending on the position and number of double bonds, may have detrimental effects on human health (Shingfield et al., 2008). Limited evidence exists to confirm putative adverse or neutral effects of trans 18:1 isomers from ruminant products is relative to partially hydrogenated vegetable oils (Brouwer et al., 2010). In contrast, dietary consumption of n-3 FA is beneficial for human health (Gebauer et al., 2006), and conjugated linoleic acid (CLA) from ruminant fat has been shown to exhibit potent anti-inflammatory and anticarcinogenic activities, and is reported to improve biomarkers of cardiovascular health in animal models or studies with human cell lines (Huth et al., 2006; Shingfield et al., 2008; Gebauer et al., 2011). For above reasons, public 
health guidelines in most developed countries have recommended population-wide reduction in saturated and trans $\mathrm{FA}$ and an increase in 18:3n-3, 20:5n-3, and 22:6n-3 in the human food chain to decrease the incidence of chronic disease (WHO, 2003). Although increasing the proportion of polyunsaturated fatty acids (PUFA) in milk is limited due to extensive biohydrogenation of these FA in the rumen, supplementing linseed to dairy cattle increased the proportion of cis-9,trans-11-18:2 (c9,t11 CLA) and n-3 FA, particularly linolenic acid, EPA and DHA in milk (Glasser et al., 2008, Lerch et al., 2012; Puppel et al., 2013). The objective of this study was to characterize milk FA composition responses to different forms of dietary linseed supplements in lactating dairy cows fed a diet based on grass silage. The hypothesis of this study was that feeding different physical forms of linseed in dairy cattle diets leads to an improvement in milk n-3 FA and CLA.

\section{MATERIALS AND METHODS}

\section{Animals, experimental design, and treatments}

Thirty six Holstein Friesian crossbred lactating dairy cows, averaging $45 \pm 8$ days in milk, $17.3 \pm 0.9 \mathrm{~kg}$ of milk and $452 \pm 18 \mathrm{~kg}$ body weight, were blocked by milking days first and then stratified randomly based on milk yield and body weight into three groups of 12 cows each. All cows were fed with $8 \mathrm{~kg} / \mathrm{d}$ of $21 \%$ crude protein $(\mathrm{CP})$ concentrate. The experimental design was a randomized complete block design with twelve replicates per each treatment. The treatments consisted of basal ration based on grass silage supplemented with $300 \mathrm{~g} / \mathrm{d}$ of palm oil as a positive control diet (PO), or supplemented with $300 \mathrm{~g} / \mathrm{d}$ linseed oil (LSO), or supplemented with $688 \mathrm{~g} / \mathrm{d}$ of top-dressed whole linseed ( $4.46 \%$ dry matter (DM) intake, WLS). The WLS contained $43.7 \%$ fat, thus the supplementation of $688 \mathrm{~g} / \mathrm{d}$ of WLS provided $300 \mathrm{~g} / \mathrm{d}$ of LSO, respectively. The level of oil supplement calculated as percent to DM intake was $1.9 \%$ in LSO and WLS treatments. The PO was added to balance energy concentration in the diets. The basal diet was formulated to meet NRC (2001) requirements (Table 1). All cows received ad libitum grass silage (Brachiaria ruziziensis; 50 d cutting age), had free access to clean water, were individually housed in a free-stall unit, and individually fed according to treatments. The experiment lasted for 10 weeks with the first 2 weeks for adjustment, followed by 8 weeks of measurement period.

\section{Measurements, sample collection, and chemical analysis}

Residual feeds were weighed for two consecutive days weekly. Feed samples were taken and dried at $60^{\circ} \mathrm{C}$ for 48 hours. At the end of the experimental period, feed samples were composited and subsamples were taken for further chemical analysis. Samples were ground through a $1 \mathrm{~mm}$ screen and subjected to proximate analysis. Crude protein content was determined by Kjeldahl method (procedure 928.08, AOAC, 1998). Ether extract was determined by using petroleum ether in a Soxtec System (procedure 948.15, AOAC, 1998). Neutral detergent fiber and acid detergent fiber were determined using the method described by Van Soest et al. (1991), adapted for Fiber Analyzer. Chemical analysis was expressed on the basis of final DM.

Cows were milked twice daily at 05.00 and $15.00 \mathrm{~h}$, and milk yields were recorded for each cow. Milk samples (evening and morning) were collected at each milking for

Table 1. Chemical composition of feed used in the experiment

\begin{tabular}{|c|c|c|c|c|c|}
\hline$\%$ Dry matter $(\mathrm{DM})$ & Concentrate $^{1}$ & Grass silage & Palm oil & Linseed oil & Whole linseed \\
\hline$\overline{\mathrm{DM}}$ & 91.02 & 28.34 & & & 91.70 \\
\hline $\mathrm{CP}$ & 21.35 & 7.61 & & & 21.34 \\
\hline Lipid & 3.87 & 2.23 & 100.00 & 100.00 & 43.70 \\
\hline Ash & 9.01 & 8.37 & & & 3.30 \\
\hline $\mathrm{CF}$ & 12.28 & 30.25 & & & 6.21 \\
\hline $\mathrm{NFC}^{2}$ & 33.81 & 27.91 & & & 3.15 \\
\hline $\mathrm{NDF}$ & 38.27 & 55.19 & & & 36.20 \\
\hline $\mathrm{ADF}$ & 16.04 & 34.28 & & & 22.30 \\
\hline $\mathrm{ADL}$ & 3.28 & 4.16 & & & 4.27 \\
\hline $\mathrm{NE}_{\mathrm{LP}}^{3}(\mathrm{Mcal} / \mathrm{kg})$ & 1.63 & 1.33 & 4.63 & 4.63 & 3.12 \\
\hline$d g \mathrm{DM}^{4}$ & 63.87 & 48.33 & & & - \\
\hline$d g \mathrm{CP}^{4}$ & 66.83 & 56.27 & & & - \\
\hline
\end{tabular}

CP, crude protein; CF, crude fiber; NFC, non-fiber carbohydrate; NDF, neutral detergent fiber; ADF, acid detergent fiber; ADL, acid detergent lignin; $\mathrm{NE}_{\mathrm{LP}}$, net energy for lactation at production level.

${ }^{1}$ Contained (as DM basis): $32 \%$ cassava distillers dried meal, $20 \%$ soybean meal, $17.5 \%$ corn distillers dried grains with solubles, $10 \%$ rice bran, $10 \%$ wheat bran, $8 \%$ molasses, and 2.5\% mineral and vitamin mix. Mineral and vitamin mix: provided per kg of concentrate including $5,000 \mathrm{IU}$ of vitamin A, 2,200 IU of vitamin $\mathrm{D}_{3}, 15 \mathrm{IU}$ of vitamin E, $8.5 \mathrm{~g}$ of Ca, $6 \mathrm{~g}$ of P, $9.5 \mathrm{~g}$ of K, $2.4 \mathrm{~g}$ of $\mathrm{Mg}, 2.1 \mathrm{~g}$ of Na, $3.4 \mathrm{~g}$ of Cl, $3.2 \mathrm{~g}$ of S, $0.16 \mathrm{mg}$ of Co, $100 \mathrm{mg}$ of $\mathrm{Cu}, 1.3 \mathrm{mg}$ of I, $64 \mathrm{mg}$ of Mn, $64 \mathrm{mg}$ of $\mathrm{Zn}, 64 \mathrm{mg}$ of Fe, and $0.45 \mathrm{mg}$ of Se.

${ }^{2}$ Calculated as 100- (CP+NDF+lipid+ash). ${ }^{3}$ Calculated using published values of NRC (2001).

${ }^{4} d g \mathrm{DM}=$ effective degradability of DM; $d g \mathrm{CP}=$ effective degradability of CP. Obtained from nylon bag technique (Ørskov and McDonald, 1979). 
two consecutive days weekly and stored at $4{ }^{\circ} \mathrm{C}$ with a preservative (bronopol tablet; D\&F Control System, San Ramon, CA, USA) until analyzed for fat, protein, lactose and solid-not-fat contents using a Milko-Scan S50 analyzer (Foss Tecator, Hillerød, Denmark). All cows were weighed at the start and end of the experiment.

Milk samples were collected from individual cow on day 56 of the experiment. Milk samples were centrifuged at $2,000 \times \mathrm{g}$ to fat cake and extraction. Lipid extraction was that of the procedures described by Hara and Radin (1978), using a volume of $18 \mathrm{~mL}$ of hexane and isopropanol (3:2, $\mathrm{v} / \mathrm{v}) / \mathrm{g}$ of fat cake. After vortexing, a sodium sulfate solution $\left(6.7 \% \mathrm{NaSO}_{4}\right.$ in distilled $\left.\mathrm{H}_{2} \mathrm{O}\right)$ was added at a volume of 12 $\mathrm{mL} / \mathrm{g}$ of fat cake. The hexane layer was transferred to a tube containing $1 \mathrm{~g}$ of $\mathrm{NaSO}_{4}$, and after $30 \mathrm{~min}$, the hexane layer was removed and stored at $-20^{\circ} \mathrm{C}$ until methylation.

Fatty acid methyl esters (FAME) were prepared by procedure described by Ostrowska et al. (2000). Briefly, the procedure required that approximately $30 \mathrm{mg}$ of the extracted oil was placed into a $15-\mathrm{mL}$ reaction tube fitted with a teflon-lined screw cap and then $1.5 \mathrm{~mL}$ of $0.5 \mathrm{M}$ sodium hydroxide in methanol was added. The tubes were flushed with nitrogen, capped, heated at $100^{\circ} \mathrm{C}$ for $5 \mathrm{~min}$ with occasional shaking and then cooled to room temperature. One $\mathrm{mL}$ of $\mathrm{C} 17: 0$ internal standard $(2 \mathrm{mg} / \mathrm{mL}$ in hexane) and $2 \mathrm{~mL}$ of $14 \%$ boron trifluoride in methanol were added and heated at $100^{\circ} \mathrm{C}$ for $5 \mathrm{~min}$ with occasional shaking. After methylation was completed, $10 \mathrm{~mL}$ of deionized water was added. The solution was transferred to a 40-mL centrifuged tube, and $5 \mathrm{~mL}$ of hexane was added for FAME extraction. The solution was centrifuged at 2,000 $\times \mathrm{g}$, at $10^{\circ} \mathrm{C}$ for $20 \mathrm{~min}$ and the hexane layer was then dried over sodium sulfate and was taken into vial for analyzed by gas chromatography (GC) (Hewlett Packard GC system HP6890 A; Hewlett Packard, Avondale, PA, USA) equipped with a $100 \mathrm{~m} \times 0.25 \mathrm{~mm}$ fused silica capillary column (SP2560, Supelco Inc, Bellefonte, PA, USA). Injector and detector temperatures were $240^{\circ} \mathrm{C}$. The column temperature was kept at $70^{\circ} \mathrm{C}$ for $4 \mathrm{~min}$, then increased at $13^{\circ} \mathrm{C} / \mathrm{min}$ to $175^{\circ} \mathrm{C}$ and held at $175^{\circ} \mathrm{C}$ for $27 \mathrm{~min}$, then increased at $4^{\circ} \mathrm{C} / \mathrm{min}$ to $215^{\circ} \mathrm{C}$ and held at $215^{\circ} \mathrm{C}$ for $31 \mathrm{~min}$.

\section{Statistical analysis}

Measurements of intake, milk production, milk composition, milk FA and body weight change were analyzed by ANOVA for a randomized complete block design using the Statistical Analysis System (SAS, 1996). Differences between treatment means were statistically compared using Least Significant Differences (Steel and Torrie, 1980).

\section{RESULTS}

The chemical compositions of the feeds are presented in Table 1. Palm oil and linseed oil were used only as a source of lipid, while WLS was rich in concentrations of both lipid $(43.70 \%)$ and crude protein $(21.34 \%)$. The palm oil was high in SFA (38.24\%) and low in n-3 FA (0.26\%); in contrast, the supplementation of LSO and WLS was chosen to reduce SFA $(10.23 \%$ and $10.80 \%$, respectively) and increase n-3 FA (52.46\% and 49.62\%, respectively) (Table 2). No significant differences were found for DM and net energy for lactation at production level $\left(\mathrm{NE}_{\mathrm{LP}}\right)$ intakes among groups (Table 3); however, the animals supplemented with WLS had greater total CP intake than those fed the other diets $(\mathrm{p}<0.05)$. In particular, $\mathrm{CP}$ intake of the animals fed WLS was 88 and $81 \mathrm{~g} / \mathrm{d}$ higher than those fed palm oil and linseed oil, respectively. In contrast to CP intake, no changes were found for milk yield and compositions among the treatments $(p>0.05)$ (Table 4$)$. The amount of dietary fat did not affect live weight of the cows over the course of the trial; however, live weight was lost at 54 and $107 \mathrm{~g} / \mathrm{d}$ in the animals fed PO and LSO, respectively, the animals fed diet added WLS increased live weight at 71

Table 2. Fatty acid composition of feeds (\% of total fatty acids) used in the experiment

\begin{tabular}{lccccc}
\hline Fatty acid & Concentrate & Grass silage & Palm oil & Linseed oil & Whole linseed \\
\hline C12:0 & 30.89 & 3.97 & 0.23 & 0.02 & nd \\
C14:0 & 13.67 & 3.01 & 0.85 & 0.36 & 0.04 \\
C16:0 & 11.98 & 28.76 & 36.77 & 5.07 & 3.53 \\
C18:0 & 2.76 & 15.74 & 0.39 & 4.78 & 7.23 \\
cis-9-C18:1 & 19.29 & 15.08 & 49.48 & 20.3 & 20.59 \\
cis-9,12-C18:2 & 12.05 & 16.68 & 11.74 & 13.98 & 18.47 \\
cis-9,12,15-C18:3 & nd & 6.07 & 0.26 & 52.46 & 49.62 \\
Unknown $_{\text {SFA }}^{1}$ & 9.36 & 10.69 & 0.28 & 0.03 & 0.52 \\
UFA $^{2}$ & 59.3 & 51.48 & 38.24 & 10.23 & 10.80 \\
UFA/SFA $^{\text {n-6 }}$ /n-3 & 31.34 & 37.83 & 61.48 & 86.74 & 88.68 \\
\hline
\end{tabular}

nd, not detected; SFA, saturated fatty acids; UFA, unsaturated fatty acids.

${ }^{1} \mathrm{SFA}=\mathrm{C} 12: 0+\mathrm{C} 14: 0+\mathrm{C} 16: 0+\mathrm{C} 18: 0 .{ }^{2} \mathrm{UFA}=$ cis-9-C18:1+cis-9,12-C18:2+cis-9,12,15-C18:3. ${ }^{3}$ cis-9,12-C18:2. ${ }^{4}$ cis-9,12,15-C18:3. 
Table 3. Effects of treatment diets on DM, CP, and $\mathrm{NE}_{\mathrm{LP}}$ intakes

\begin{tabular}{|c|c|c|c|c|c|}
\hline \multirow{2}{*}{ Intake } & \multicolumn{3}{|c|}{ Treatment $^{1}$} & \multirow{2}{*}{ SEM } & \multirow{2}{*}{$\mathrm{p}$-value } \\
\hline & PO & LSO & WLS & & \\
\hline \multicolumn{6}{|l|}{$\overline{\mathrm{DM}}(\mathrm{kg} / \mathrm{d})$} \\
\hline Concentrate & 7.28 & 7.28 & 7.28 & & \\
\hline Grass silage & $8.13^{\mathrm{ab}}$ & $8.22^{\mathrm{a}}$ & $7.53^{\mathrm{b}}$ & 0.21 & 0.04 \\
\hline PO/WLS & $0.30^{\mathrm{b}}$ & $0.30^{\mathrm{b}}$ & $0.63^{\mathrm{a}}$ & 0.08 & 0.02 \\
\hline Total & 15.71 & 15.80 & 15.44 & 0.23 & 0.54 \\
\hline \multicolumn{6}{|l|}{$\mathrm{CP}(\mathrm{g} / \mathrm{d})$} \\
\hline Concentrate & 1536 & 1536 & 1536 & & \\
\hline Grass silage & $619^{\mathrm{ab}}$ & $626^{\mathrm{a}}$ & $573^{\mathrm{b}}$ & 16.13 & 0.05 \\
\hline PO/WLS & 0 & 0 & 134 & & \\
\hline Total & $2155^{\mathrm{b}}$ & $2162^{\mathrm{b}}$ & $2243^{\mathrm{a}}$ & 16.15 & 0.03 \\
\hline \multicolumn{6}{|l|}{$\mathrm{NE}_{\mathrm{LP}}(\mathrm{Mcal} / \mathrm{d})$} \\
\hline Concentrate & 11.87 & 11.87 & 11.87 & & \\
\hline Grass silage & 10.81 & 10.94 & 10.01 & 0.31 & 0.26 \\
\hline PO/WLS & $1.39^{\mathrm{b}}$ & $1.39^{\mathrm{b}}$ & $1.97^{\mathrm{a}}$ & 0.13 & 0.03 \\
\hline Total & 24.07 & 24.20 & 23.85 & 0.31 & 0.45 \\
\hline
\end{tabular}

$\mathrm{DM}$, dry matter; $\mathrm{CP}$, crude protein; $\mathrm{NE}_{\mathrm{LP}}$, net energy for lactation at production level; SEM, standard error of the mean.

${ }^{1} \mathrm{PO}=$ supplemented with $300 \mathrm{~g} / \mathrm{d}$ palm oil as positive control diet; $\mathrm{LSO}=$ supplemented with $300 \mathrm{~g} / \mathrm{d}$ linseed oil; WLS = supplemented with 688 $\mathrm{g} / \mathrm{d}$ whole linseed.

a,b Means within a row with different superscripts are significantly different $(\mathrm{p}<0.05)$.

g/d (Table 4).

In the current study, linseed-containing diets resulted in marked alternations in milk FA composition and yield relative to the diet added palm oil (Tables 5 and 6). The LSO and WLS diets led to a decrease of C12:0-C16:0 FA $(\mathrm{p}<0.05)$ and an increase of trans-9-C18:1, trans-9,12$\mathrm{C} 18: 2$ and cis-9,12,15-C18:3 ( $\mathrm{p}<0.01)$ compared to the PO diet. However, cis-9-C18:1, cis-9,12-C18:2, and cis-6,9,1218:3 remained unchanged among the treatments $(p>0.05)$. The diets containing linseed resulted in greater milk fat cis9,12,15-C18:3, representing respectively $0.91 \%$ and $1.03 \%$ of the total milk FA from animals fed LSO and WLS diets compared to $0.54 \%$ in the animals fed the control diet $(\mathrm{p}<0.01)$. As the result of biohydrogenation of linoleic acid in the rumen and synthesis of CLA from trans-9-C18:1 in the mammary gland, milk cis-9,trans-11-CLA significantly increased in the LSO and WLS diets $(1.62 \%$ and $1.72 \%$, respectively) compared to $0.70 \%$ in the control diet $(\mathrm{p}<0.05)$. The concentrations of milk EPA and DHA, n-3 FA, were also improved fromanimals fed diets supplemented with LSO and WLS ( $<<0.01)$. As a result, the animals fed LSO and WLS diets decreased milk SFA $(49.91 \%$ and $49.14 \%$ ) and increased milk unsaturated fatty acids (UFA) (37.83\% and 38.64\%) compared to the animals fed PO diet $(60.59 \%$ and $31.56 \%$, respectively), accompanied by increasing UFA to SFA ratio in the linseed-containing groups relative to the control group $(\mathrm{p}<0.01)$. The proportion of total n-3 FA significantly increased $(p<0.01)$ in the animals fed diets containing linseed that led to a decrease $(\mathrm{p}<0.01)$ in the ratio of $\mathrm{n}-6$ to $\mathrm{n}-3 \mathrm{FA}$ in their milk fat. The animals fed diets supplemented with LSO and WLS

Table 4. Effects of treatment diets on milk yield, milk composition, and live weight change

\begin{tabular}{|c|c|c|c|c|c|}
\hline \multirow{2}{*}{ Yield } & \multicolumn{3}{|c|}{ Treatment $^{1}$} & \multirow{2}{*}{ SEM } & \multirow{2}{*}{ p-value } \\
\hline & $\mathrm{PO}$ & LSO & WLS & & \\
\hline \multicolumn{6}{|l|}{ Yield } \\
\hline $\operatorname{Milk}(\mathrm{kg} / \mathrm{d})$ & 18.1 & 18.3 & 18.6 & 0.97 & 0.69 \\
\hline $3.5 \% \mathrm{FCM}^{2}(\mathrm{~kg} / \mathrm{d})$ & 18.5 & 19.0 & 19.4 & 0.96 & 0.67 \\
\hline Fat $(\mathrm{g} / \mathrm{d})$ & 659 & 681 & 703 & 62 & 0.35 \\
\hline Protein $(\mathrm{g} / \mathrm{d})$ & 529 & 551 & 564 & 51 & 0.82 \\
\hline Lactose $(\mathrm{g} / \mathrm{d})$ & 896 & 899 & 917 & 76 & 0.70 \\
\hline Solid-not-fat (g/d) & 1,627 & 1,636 & 1,642 & 103 & 0.68 \\
\hline Total solid $(\mathrm{g} / \mathrm{d})$ & 2,286 & 2,317 & 2,345 & 142 & 0.61 \\
\hline \multicolumn{6}{|c|}{ Composition ( $\mathrm{g} / 100 \mathrm{~g}$ of raw milk) } \\
\hline Fat & 3.64 & 3.72 & 3.78 & 0.22 & 0.66 \\
\hline Protein & 2.92 & 3.01 & 3.03 & 0.14 & 0.60 \\
\hline Lactose & 4.95 & 4.91 & 4.93 & 0.34 & 0.87 \\
\hline Solid-not-fat & 8.99 & 8.94 & 8.83 & 0.41 & 0.74 \\
\hline Total solid & 12.63 & 12.66 & 12.61 & 0.45 & 0.81 \\
\hline \multicolumn{6}{|l|}{ Live weight change } \\
\hline Initial live weight (kg) & 454 & 451 & 453 & 11.7 & 0.58 \\
\hline Final live weight $(\mathrm{kg})$ & 451 & 445 & 457 & 12.4 & 0.67 \\
\hline Live weight gain (g/d) & -54 & -107 & +71 & 103 & 0.56 \\
\hline
\end{tabular}

SEM, standard error of the mean; FCM, fat-corrected milk.

${ }^{1} \mathrm{PO}=$ supplemented with $300 \mathrm{~g} / \mathrm{d}$ palm oil as positive control diet; LSO = supplemented with $300 \mathrm{~g} / \mathrm{d}$ linseed oil; WLS = supplemented with $688 \mathrm{~g} / \mathrm{d}$ whole linseed.

${ }^{2} 3.5 \% \mathrm{FCM}=(0.432 \times \mathrm{kg}$ of milk $)+(16.216 \times \mathrm{kg}$ of milk fat $)$. 
Table 5. Milk fatty acid composition ( $\mathrm{g} / 100 \mathrm{~g}$ FA) of cows fed linseed oil or whole linseed

\begin{tabular}{|c|c|c|c|c|c|}
\hline \multirow{2}{*}{ Fatty acid } & \multicolumn{3}{|c|}{ Treatment $^{1}$} & \multirow{2}{*}{ SEM } & \multirow{2}{*}{ p-value } \\
\hline & $\mathrm{PO}$ & LSO & WLS & & \\
\hline C4:0 & 1.36 & 1.25 & 1.22 & 0.07 & 0.56 \\
\hline C6:0 & 1.21 & 1.06 & 1.08 & 0.07 & 0.58 \\
\hline C8:0 & 0.68 & 0.57 & 0.55 & 0.06 & 0.47 \\
\hline C10:0 & 1.49 & 1.25 & 1.20 & 0.12 & 0.28 \\
\hline $\mathrm{C} 12: 0$ & $1.76^{\mathrm{a}}$ & $1.51^{\mathrm{b}}$ & $1.45^{\mathrm{b}}$ & 0.08 & 0.04 \\
\hline $\mathrm{C} 14: 0$ & $7.84^{\mathrm{a}}$ & $6.92^{\mathrm{b}}$ & $6.87^{\mathrm{b}}$ & 0.16 & 0.03 \\
\hline C16:0 & $28.97^{\mathrm{a}}$ & $23.46^{\mathrm{b}}$ & $22.97^{\mathrm{b}}$ & 0.62 & 0.01 \\
\hline $\mathrm{C} 17: 0$ & 0.91 & 0.83 & 0.82 & 0.03 & 0.09 \\
\hline C18:0 & $16.37^{\mathrm{a}}$ & $13.06^{\mathrm{b}}$ & $12.98^{\mathrm{b}}$ & 0.97 & 0.02 \\
\hline trans-9- C18:1 & $3.72^{\mathrm{b}}$ & $8.55^{\mathrm{a}}$ & $9.02^{\mathrm{a}}$ & 0.83 & 0.01 \\
\hline cis-9-C18:1 & 24.13 & 23.27 & 23.23 & 1.21 & 0.28 \\
\hline trans $-9,12-\mathrm{C} 18: 2$ & $0.26^{\mathrm{b}}$ & $1.15^{\mathrm{a}}$ & $1.22^{\mathrm{a}}$ & 0.13 & 0.01 \\
\hline cis-9,12-C18:2 & 2.02 & 1.87 & 1.85 & 0.12 & 0.12 \\
\hline cis-6,9,12-18:3 & 0.29 & 0.31 & 0.30 & 0.04 & 0.87 \\
\hline cis-9,12,15-C18:3 & $0.54^{\mathrm{b}}$ & $0.91^{\mathrm{a}}$ & $1.03^{\mathrm{a}}$ & 0.07 & 0.01 \\
\hline cis-9,trans-11-CLA & $0.70^{\mathrm{b}}$ & $1.62^{\mathrm{a}}$ & $1.72^{\mathrm{a}}$ & 0.30 & 0.04 \\
\hline trans,trans -CLA & $0.12^{\mathrm{b}}$ & $0.28^{\mathrm{ab}}$ & $0.33^{\mathrm{a}}$ & 0.06 & 0.04 \\
\hline C20:5n-3, EPA & $0.01^{\mathrm{b}}$ & $0.04^{\mathrm{a}}$ & $0.06^{\mathrm{a}}$ & $<0.01$ & 0.01 \\
\hline$C 22: 4 n-6$ & $0.02^{\mathrm{b}}$ & $0.04^{\mathrm{a}}$ & $0.05^{\mathrm{a}}$ & $<0.001$ & 0.01 \\
\hline$C 22: 5 n-3$ & $0.03^{\mathrm{b}}$ & $0.06^{\mathrm{a}}$ & $0.07^{\mathrm{a}}$ & $<0.001$ & 0.01 \\
\hline C22:6n-3, DHA & $0.01^{\mathrm{b}}$ & $0.04^{\mathrm{a}}$ & $0.06^{\mathrm{a}}$ & $<0.001$ & 0.01 \\
\hline Unknown & 7.85 & 12.26 & 12.22 & 1.68 & 0.12 \\
\hline SFA & $60.59^{\mathrm{a}}$ & $49.91^{\mathrm{b}}$ & $49.14^{\mathrm{b}}$ & 0.97 & 0.02 \\
\hline UFA & $31.56^{\mathrm{b}}$ & $37.83^{\mathrm{a}}$ & $38.64^{\mathrm{a}}$ & 0.97 & 0.02 \\
\hline$n-6 F A^{2}$ & $2.60^{\mathrm{b}}$ & $3.41^{\mathrm{a}}$ & $3.48^{\mathrm{a}}$ & 0.05 & 0.01 \\
\hline$n-3 F A^{3}$ & $0.59^{c}$ & $1.05^{\mathrm{b}}$ & $1.22^{\mathrm{a}}$ & 0.03 & 0.01 \\
\hline$n-6 / n-3$ & $4.41^{\mathrm{a}}$ & $3.25^{\mathrm{a}}$ & $2.85^{\mathrm{b}}$ & 0.09 & 0.01 \\
\hline \multicolumn{6}{|l|}{ Indices $^{4}$} \\
\hline $\mathrm{M} / \mathrm{S}$ & $0.46^{\mathrm{b}}$ & $0.64^{\mathrm{a}}$ & $0.66^{\mathrm{a}}$ & 0.02 & 0.01 \\
\hline $\mathrm{P} / \mathrm{S}$ & $0.05^{\mathrm{b}}$ & $0.09^{\mathrm{a}}$ & $0.09^{\mathrm{a}}$ & 0.01 & 0.01 \\
\hline $\mathrm{U} / \mathrm{S}$ & $0.52^{\mathrm{b}}$ & $0.76^{\mathrm{a}}$ & $0.79^{\mathrm{a}}$ & 0.01 & 0.01 \\
\hline
\end{tabular}

SEM, standard error of the mean; CLA, conjugated linoleic acid; SFA, saturated fatty acids; UFA, unsaturated fatty acids.

${ }^{1} \mathrm{PO}=$ supplemented with $300 \mathrm{~g} / \mathrm{d}$ palm oil as positive control diet; LSO = supplemented with $300 \mathrm{~g} / \mathrm{d}$ linseed oil; WLS = supplemented with $688 \mathrm{~g} / \mathrm{d}$ whole linseed.

${ }^{2}$ Calculated as trans-9,12-C18:2+cis-9,12-C18:2+cis-6,9,12-18:3+C22:4n-6.

${ }^{3}$ Calculated as cis-9,12,15-C18:3+C20:5n-3+C22:5n-3+C22:6n-3.

${ }^{4} \mathrm{M} / \mathrm{S}=$ sum of monounsaturated fatty acids/sum of saturated fatty acids; $\mathrm{P} / \mathrm{S}=$ sum of polyunsaturated fatty acids/sum of saturated fatty acids; U/S = sum of unsaturated fatty acids/sum of saturated fatty acids.

${ }^{\mathrm{a}, \mathrm{b}}$ Means within a row with different superscripts are significantly different $(\mathrm{p}<0.05)$

had respectively $68.5 \%$ and $90.7 \%$ more cis-9,12,15-C18:3 and $131 \%$ and $146 \%$ higher cis-9,trans-11-CLA, and $130 \%$ and $142 \%$ higher milk trans-C18:1 than those fed PO diet. The LSO and WLS supplementation significantly increased the yields of trans-C18:1, cis-9,12,15-C18:3 ( $\mathrm{p}<0.01)$, and cis-9,trans-11-CLA $(\mathrm{p}<0.01)$ while it did not affect the main of n-6 FA (cis-9,12-C18:2; p>0.10). Decreased SFA and increased UFA yields were also found as the animals fed diets comprising LSO and WLS $(p<0.05)$. The average daily yields of total n-3 FA in the LSO and WLS diets were improved respectively up to 7.15 and 8.58 $\mathrm{g} / \mathrm{d}, 83.8 \%$ and $121 \%$ higher than PO diet $(\mathrm{p}<0.01)$.
Consequently, the ratio of n-6 to n-3 FA was reduced in the animals fed WSO-containing diet (2.85) compared to 4.41 in the PO diet-fed animals $(\mathrm{p}<0.01)$.

\section{DISCUSSION}

The foremost consideration to supplement linseed in dairy cow feeding is potential adverse effects of FA from linseed on feed intake and lactation performance. The intakes of $\mathrm{DM}$ and $\mathrm{NE}_{\mathrm{LP}}$ in the current study were in agreement with most literature reports that showed lesser effects of concentration and type of fat supplement when 
Table 6. Milk fatty acid yield (g/d) of cows fed linseed oil or whole linseed

\begin{tabular}{|c|c|c|c|c|c|}
\hline \multirow{2}{*}{ Fatty acid } & \multicolumn{3}{|c|}{ Treatment $^{1}$} & \multirow{2}{*}{ SEM } & \multirow{2}{*}{ p-value } \\
\hline & $\mathrm{PO}$ & LSO & WLS & & \\
\hline$\overline{\mathrm{C} 4: 0}$ & 8.96 & 8.51 & 8.58 & 0.477 & 0.56 \\
\hline C6:0 & 7.97 & 7.22 & 7.59 & 0.477 & 0.58 \\
\hline C8:0 & 4.48 & 3.88 & 3.87 & 0.408 & 0.47 \\
\hline C10:0 & 9.82 & 8.51 & 8.44 & 0.817 & 0.28 \\
\hline C12:0 & 11.60 & 10.28 & 10.19 & 0.545 & 0.61 \\
\hline C14:0 & 51.65 & 47.11 & 48.30 & 1.089 & 0.22 \\
\hline $\mathrm{C} 16: 0$ & $190.87^{\mathrm{a}}$ & $159.71^{\mathrm{b}}$ & $161.50^{\mathrm{b}}$ & 4.221 & 0.01 \\
\hline $\mathrm{C} 17: 0$ & 6.00 & 5.65 & 5.77 & 0.204 & 0.39 \\
\hline C18:0 & 107.85 & 88.91 & 91.26 & 6.604 & 0.42 \\
\hline trans-9- C18:1 & $24.51^{\mathrm{b}}$ & $58.20^{\mathrm{a}}$ & $63.42^{\mathrm{a}}$ & 5.650 & 0.01 \\
\hline cis-9-C18:1 & 158.98 & 158.41 & 163.33 & 8.237 & 0.28 \\
\hline trans-9,12-C18:2 & $1.71^{\mathrm{b}}$ & $7.83^{\mathrm{a}}$ & $8.58^{\mathrm{a}}$ & 0.885 & 0.01 \\
\hline cis-9,12-C18:2 & 13.31 & 12.73 & 13.01 & 0.817 & 0.12 \\
\hline cis-6,9,12-18:3 & 1.91 & 2.11 & 2.11 & 0.272 & 0.87 \\
\hline cis-9,12,15-C18:3 & $3.56^{\mathrm{b}}$ & $6.19^{\mathrm{a}}$ & $7.24^{\mathrm{a}}$ & 0.477 & 0.01 \\
\hline cis-9,trans-11-CLA & $4.61^{\mathrm{b}}$ & $11.03^{\mathrm{a}}$ & $12.09^{\mathrm{a}}$ & 2.042 & 0.04 \\
\hline trans,trans -CLA & 0.79 & 1.91 & 2.32 & 0.408 & 0.23 \\
\hline C20:5n-3, EPA & $0.07^{\mathrm{c}}$ & $0.27^{\mathrm{b}}$ & $0.42^{\mathrm{a}}$ & $<0.01$ & 0.01 \\
\hline$C 22: 4 n-6$ & $0.13^{\mathrm{c}}$ & $0.27^{\mathrm{b}}$ & $0.35^{\mathrm{a}}$ & $<0.001$ & 0.01 \\
\hline$C 22: 5 n-3$ & $0.20^{\mathrm{c}}$ & $0.41^{\mathrm{b}}$ & $0.49^{\mathrm{a}}$ & $<0.001$ & 0.01 \\
\hline C22:6n-3, DHA & $0.07^{\mathrm{c}}$ & $0.27^{\mathrm{b}}$ & $0.42^{\mathrm{a}}$ & $<0.001$ & 0.01 \\
\hline Unknown & 51.72 & 83.46 & 85.92 & 1.68 & 0.12 \\
\hline SFA & $399.19^{\mathrm{a}}$ & $339.77^{\mathrm{c}}$ & $345.49^{b}$ & 0.97 & 0.02 \\
\hline UFA & $207.93^{c}$ & $257.53^{\mathrm{b}}$ & $271.67^{\mathrm{a}}$ & 0.97 & 0.02 \\
\hline$n-6 F A^{2}$ & $17.13^{\mathrm{c}}$ & $23.21^{\mathrm{b}}$ & $24.47^{\mathrm{a}}$ & 0.340 & 0.01 \\
\hline$n-3 F A^{3}$ & $3.89^{c}$ & $7.15^{\mathrm{b}}$ & $8.58^{\mathrm{a}}$ & 0.204 & 0.01 \\
\hline$n-6 / n-3$ & $4.41^{\mathrm{a}}$ & $3.25^{\mathrm{a}}$ & $2.85^{\mathrm{b}}$ & 0.09 & 0.01 \\
\hline \multicolumn{6}{|l|}{ Indices $^{4}$} \\
\hline $\mathrm{M} / \mathrm{S}$ & $0.46^{\mathrm{b}}$ & $0.64^{\mathrm{a}}$ & $0.66^{\mathrm{a}}$ & 0.02 & 0.01 \\
\hline $\mathrm{P} / \mathrm{S}$ & $0.05^{\mathrm{b}}$ & $0.09^{\mathrm{a}}$ & $0.09^{\mathrm{a}}$ & 0.01 & 0.01 \\
\hline $\mathrm{U} / \mathrm{S}$ & $0.52^{\mathrm{b}}$ & $0.76^{\mathrm{a}}$ & $0.79^{\mathrm{a}}$ & 0.01 & 0.01 \\
\hline
\end{tabular}

SEM, standard error of the mean; CLA, conjugated linoleic acid; SFA, saturated fatty acids; UFA, unsaturated fatty acids.

${ }^{1} \mathrm{PO}=$ supplemented with $300 \mathrm{~g} / \mathrm{d}$ palm oil as positive control diet; LSO = supplemented with $300 \mathrm{~g} / \mathrm{d}$ linseed oil; WLS = supplemented with $688 \mathrm{~g} / \mathrm{d}$ whole linseed.

${ }^{2}$ Calculated as trans-9,12-C18:2+cis-9,12-C18:2+cis-9,12,15-C18:3+C22:4n-6.

${ }^{3}$ Calculated as cis-9,12,15-C18:3+C20:5n-3+C22:5n-3+C22:6n-3.

${ }^{4} \mathrm{M} / \mathrm{S}=$ sum of monounsaturated fatty acids/sum of saturated fatty acids; $\mathrm{P} / \mathrm{S}=$ sum of polyunsaturated fatty acids/sum of saturated fatty acids; U/S = sum of unsaturated fatty acids/sum of saturated fatty acids.

${ }^{\mathrm{a}-\mathrm{c}}$ Means within a row with different superscripts are significantly different $(\mathrm{p}<0.05)$

total fat concentration was less than $6 \%$ of the DM (Lunsin et al., 2012; Dirandeh et al., 2013; Mach et al., 2013). The animals fed WLS had greater CP intake due to the higher $\mathrm{CP}$ concentration in the whole linseed compared to palm oil and linseed oil. The effect of unsaturated FA from LSO and WLS on feed intake has been variable among previous studies. Chilliard et al. (2009) reported that dairy cows' diet based on corn silage and grass hay (65.1:34.9 forage:concentrate $[\mathrm{F}: \mathrm{C}]$ ratio, DM basis) supplemented with oil from whole crude linseed at $4.2 \%$ of dietary DM had no effect on feed intake. In addition, Shingfield et al. (2011) found no effect of 3\% LSO supplementation to a corn silage-based diet (60:40 F:C, DM basis) of growing steers on DMI. This result was supported by Benchaar et al. (2012) that LSO supplementation at $2 \%, 3 \%$, or $4 \%$ DM to lactating dairy cows fed a total mixed ration with a R/C ratio of 50:50 had no effect on DM intake and digestibility of nutrients. In contrast, Martin et al. (2008) concluded that lactating dairy cows fed a diet supplemented with LSO at $5.7 \%$ DM had significantly lower DMI compared to the control diet, while no negative effects were found when dairy cows were supplemented with crude linseed or extruded linseed. A similar result was also found in the recent study of Lerch et al. (2012) where dairy cows were 
supplied with $3.0 \%$ oil (DM basis) from extruded linseed in the basal diet containing 60:40 $\mathrm{F}: \mathrm{C}$ ratio. It is possible that FA intake has a direct inhibitory effect on voluntary intake via inhibition of rumino-recticular motility (Chilliard, 1993). In general, these results suggest that the effect of unsaturated fat from linseed on DMI varies with the amount of added fat, fat type, and $\mathrm{F}: \mathrm{C}$ ratio of the diet.

Supplementation of LSO and oil from WLS at $300 \mathrm{~g} / \mathrm{d}$ had no effect on milk yield. Unchanged milk yield was also reported in the studies (Caroprese et al., 2010; Lerch et al., 2012; Weisbjerg et al., 2013). Moreover, dairy cows were supplemented with $13 \%$ extruded linseed increased milk yield (Mach et al., 2013). In contrast, supplementation of linseed oil decreased milk yield of dairy cows (Brown et al., 2008; Martin et al., 2008) Indeed, the decrease in milk production reported in some previous studies was associated with a depression in DMI and diet digestibility due to disturbances in rumen function caused by a high level of LSO intake (i.e., >5\% of DMI). Discrepancies among studies on effect of linseed supplementation on milk yield of dairy cows might be due to the form of oil, added level, and different duration of the experiment. Allen (2000) concluded that supplementing FA from hydrogenated fat and oilseeds at approximately 23 and $30 \mathrm{~g} / \mathrm{kg}$ DM added fat, respectively, has no effect on DMI, which may contribute to the explainatioon of why milk yield of dairy cows fed high PUFA-containing diet was similar to those fed high monoand saturated FA-comprising diet in the current study.

In the current study, supplementing LSO or oil from WLS had no effect on milk concentrations and yields of fat, protein, and lactose which agreed with previous studies (Côrtes et al., 2010; Petit and Côrtes, 2010; Lerch et al., 2012). Similarly, inclusion of $56 \mathrm{~g} / \mathrm{kg} \mathrm{DM}$ ground rapeseed plus $19 \mathrm{~g} / \mathrm{kg}$ DM ground linseed in the diet of Danish Holstein cows had no effect on milk fat concentration and yield (Weisbjerg et al., 2013). In contrast, dairy cows fed a diet supplemented with 3.1\% LSO plus DHA Gold algae (Angulo et al., 2012) had lower milk fat yield compared to the control group fed a basal diet supplemented with $3.1 \%$ protected saturated fat. A latter research also reported reduction of milk fat concentration and yield as dairy cows were supplemented with $4.03 \%$ DM extruded linseed (Dirandeh et al., 2013); however, no effect was found in concentration of milk protein and lactose. The decrease in milk fat concentration in some previous studies was attributed to lower DMI and nutrient digestibility, particularly fiber, due to the high level of oil ingested (Martin et al., 2008) and lower mammary lipogenesis resulting from supplementing polyunsaturated oil when cows were fed a starch-rich diet (Chilliard et al., 2007).

Dairy milk fat contains over 400 individual FA and their isomers. Cow milk contains large amounts of SFA, particularly $\mathrm{C} 14: 0$ and $\mathrm{C} 16: 0$, which lead to physiological dysfunctions including higher plasma cholesterol, and small amounts of mono-unsaturated fatty acids (MUFA), PUFA, and n-3 FA which have beneficial effects on human health. The important concern is how to alter the milk FA profile to make it more suitable for human health. One suggestion is to use an organic system (Tudisco et al., 2010), or feed whole oleaginous plants or oils from them to the cows. Oil from linseed may influence milk FA levels as follows: i) decrease SFA, ii) increase UFA, iii) increase the proportion of the CLA and of the $\alpha$-linolenic acid, and iv) decrease the n-6 FA to n-3 FA ratio. These possible changes rely on the very high level of C18:3n-3 in flax seeds (40\% to $45 \%$ ). In this study, the lower concentration of milk medium chain FA, particularly C12:0-C16:0 FA, in the LSO and WLS diets indicated less de novo FA synthesis occurred with the animals fed these treatments. For this reason, feeding high PUFA oils are typically associated with a reduction in the de novo synthesis of short- and medium- chain FA (Brown et al., 2008; Lerch et al., 2012; Weisbjerg et al., 2013). The decrease in milk C12:0-C16:0 concentrations from linseedsupplemented cows may be a positive goal from a human health perspective because high proportions of $\mathrm{C} 14: 0$ and C16:0 have been shown to combine with human cardiovascular problems (Noakes et al., 1996). The improvement of milk concentrations and yields of n-3 FA, particularly linolenic acid, and CLA in the cows fed diets containing LSO or WLS in the current study was in agreement with some previous studies (Lerch et al., 2012; Mach et al., 2013; Weisbjerg et al., 2013). The higher milk cis-9,trans-11-CLA originates from ruminal biohydrogenation of linoleic acid as an intermediate product or from endogenous synthesis in the mammary gland from vaccenic acid (VA) (Griinari and Bauman, 1999). The endogenous synthesis of cis-9,trans-11-CLA from VA has been showed as the major pathway of cis-9,trans-11-CLA synthesis in lactating cows, accounting for an estimated $80 \%$ of the cis-9,trans-11-CLA in milk fat (Mosley et al., 2006). Milk from LSO and WLS-supplied cows together with the high CLA concentration was characterized by low atherogenic and thrombogenic indices, suggesting that its utilization has less detrimental effects concerning the atherosclerosis and coronary thrombosis risk associated with the consumption of milk and dairy products, consequently being potentially healthier for humans. The average concentration of milk linolenic acid in the study was in agreement with Moate et al. (2007) who reported on 28 publications, that the average level of cis-9,12,15-C18:3 in the milk was $5.9 \%$ of the total FA, with a range from 0.2 to 19. A decrease of n-6 FA alongside an increase of n-3 FA led to a decrease of n-6 FA to n-3 FA ratio in milk of cows fed LSO and WLS. Lowering the ratio of n-6 to n-3 FA in food products has been recommended to prevent or modulate certain diseases in humans (Connor, 2000). Milk 
from cows supplemented with LSO and WLS represented an improvement in the FA profile, with an increase in the MUFA, PUFA, and total UFA concentrations and a decrease in SFA concentration, resultant in increased indices of MUFA, PUFA and UFA to SFA. These results were in agreement with recent studies (Caroprese et al., 2010; Petit and Côrtes, 2010; Lerch et al., 2012), which reported similar changes in milk FA when flaxseed supplements were used.

\section{CONCLUSION}

The present study clearly indicated that supplementation of whole linseed to lactating dairy cows had no effect on milk yield and milk composition; however, trans-9-C18:1, cis-9,trans-11-CLA, n-3 FA and unsaturated FA were increased and SFA were decreased by WLS supplementation. Therefore, $300 \mathrm{~g} / \mathrm{d}$ of oil from whole linseed should be supplemented to lactating dairy cows' diets.

\section{ACKNOWLEDGMENTS}

Authors would like to express special thanks to the Dairy Farming Promotion Organization of Thailand (DPO), the Center for Scientific and Technological Equipment for their great support. Financial support was provided by the Institute of Research and Development, Suranaree University of Technology.

The work was supported by the Institute of Research and Development, Suranaree University of Technology.

\section{REFERENCES}

Allen, M. S. 2000. Effects of diet on short-term regulation of feed intake by lactating dairy cattle. J. Dairy Sci. 83:1598-1624.

Angulo, J., B. Hiller, M. Olivera, L. Mahecha, D. Dannenberger, G. Nuernberg, B. Losand, and K. Nuernberg. 2012. Dietary fatty acid intervention of lactating cows simultaneously affects lipid profiles of meat and milk. J. Sci. Food Agric. 92:2968-2974.

AOAC. 1998. Official Method of Analysis. Association of Official Analytical Chemists, Washington DC, USA.

Benchaar, C., G. A. Romero-Pérez, P. Y. Chouinard, F. Hassanat, M. Eugene, H. V. Petit, and C. Côrte. 2012. Supplementation of increasing amounts of linseed oil to dairy cows fed total mixed rations: Effects on digestion, ruminal fermentation characteristics, protozoal populations, and milk fatty acid composition. J. Dairy Sci. 95:4578-4590.

Brouwer, I. A., A. J. Wanders, and M. B. Katan. 2010. Effect of animal and industrial trans fatty acids on HDL and LDL cholesterol levels in humans-A quantitative review. PLoS ONE 5(3): 9434.

Brown, W., A. A. AbuGhazaleh, and S. A. Ibrahim. 2008. Milk conjugated linoleic acid response to fish oil and linseed oil supplementation of grazing dairy cows. Asian Australas. J.
Anim. Sci. 21:663-670.

Caroprese, M., A. Marzano, R. Marino, G. Gliatta, A. Muscio, and A. Sevi. 2010. Flaxseed supplementation improves fatty acid profile of cow milk. J. Dairy Sci. 93:2580-2588.

Chilliard, Y. 1993. Dietary fat and adipose tissue metabolism in ruminants, pigs and rodents: A review. J. Dairy Sci. 76:38973931.

Chilliard, Y., F. Glasser, A. Ferlay, L. Bernard, J. Rouel, and M. Doreau. 2007. Diet, rumen biohydrogenation, cow and goat milk fat nutritional quality: A review. Eur. J. Lipid Sci. Technol. 109:828-855.

Chilliard, Y., C. Martin, J. Rouel, and M. Doreau. 2009. Milk fatty acids in dairy cows fed whole crude linseed, extruded linseed, or linseed oil, and their relationship with methane output. J. Dairy Sci. 92:5199-5211.

Connor, W. E. 2000. Importance of n-3 fatty acids in health and disease. Am. J. Clin. Nutr. 71:171S-175S.

Côrtes, C., D. C. da Silva-Kazama, R. Kazama, N. Gagnon, C. Benchaar, G. T. D. Santos, L. M. Zeoula, and H. V. Petit. 2010. Milk composition, milk fatty acid profile, digestion, and ruminal fermentation in dairy cows fed whole flaxseed and calcium salts of flaxseed oil. J. Dairy Sci. 93:3146-3157.

Dirandeh, E., A. Towhidi, S. Zeinoaldini, M. Ganjkhanlou, Z. A. Pirsaraei, and A. Fouladi-Nashta. 2013. Effects of different polyunsaturated fatty acid supplementations during the postpartum periods of early lactating dairy cows on milk yield, metabolic responses, and reproductive performances. J. Anim. Sci. 91:713-721.

Gebauer, S. K., J. M. Chardigny, M. U. Jakobsen, B. Lamarche, A. L. Lock, S. D. Proctor, and D. J. Baer. 2011. Effects of ruminant trans fatty acids on cardiovascular disease and cancer: A comprehensive review of epidemiological, clinical, and mechanistic studies. Adv. Nutr. 2:332-354.

Gebauer, S. K., T. L. Psota, W. S. Harris, and P. M. Kris-Etherton. 2006. n-3 fatty acid dietary recommendations and food sources to achieve essentiality and cardiovascular benefits. Am. J. Clin. Nutr. 83:S1526-S1535S.

Glasser, F., A. Ferlay, and Y. Chilliard. 2008. Oilseed lipid supplements and fatty acid composition of cow milk: A metaanalysis. J. Dairy Sci. 91:4687-4703.

Griinari, J. M. and D. E. Bauman. 1999. Biosynthesis of conjugated linoleic acid and its incorporation into meat and milk in ruminants. In: Advances in Conjugated Linoleic Acid Research (Eds. M. P. Yurawecz, M. M. Mossoba, J. K. G. Kramer, M. W. Pariza, and G. J. Nelson), Vol. I (Eds). AOCS Press, Champaign, IL, USA. pp. 180-200.

Hara, A. and N. S. Radin. 1978. Lipid extraction of tissues with a low-toxicity solvent. Anal. Biochem. 90:420-426.

Huth, P. J., D. B. DiRienzo, and G. D. Miller. 2006. Major scientific advances with dairy foods in nutrition and health. J. Dairy Sci. 89:1207-1221.

Joyce, T., A. J. Wallace, S. N. McCarthy, and M. J. Gibney. 2009. Intakes of total fat, saturated, monounsaturated and polyunsaturated fatty acids in Irish children, teenagers and adults. Public Health Nutr. 12:156-165.

Lerch, S., A. Ferlay, K. J. Shingfield, B. Martin, D. Pomiès, and Y. Chilliard. 2012. Rapeseed or linseed supplements in grassbased diets: Effects on milk fatty acid composition of Holstein cows over two consecutive lactations. J. Dairy Sci. 95:5221- 
5241.

Lunsin, R., M. Wanapat, C. Yuangklang, and P. Rowlinson. 2012. Effect of rice bran oil supplementation on rumen fermentation, milk yield and milk composition in lactating dairy cows. Livest. Sci. 145:167-173.

Mach, N., R. L. G. Zom, H. C. A. Widjaja, P. G. van Wikselaar, R. E. Weurding, R. M. A. Goselink, J. van Baal, M. A. Smits, and A. M. van Vuuren. 2013. Dietary effects of linseed on fatty acid composition of milk and on liver, adipose and mammary gland metabolism of periparturient dairy cows. J. Anim. Physiol. Anim. Nutr. 97:89-104.

Martin, C., J. Rouel, J. P. Jouany, M. Doreau, and Y. Chilliard. 2008. Methane output and diet digestibility in response to feeding dairy cows crude linseed, extruded linseed, or linseed oil. J. Anim. Sci. 86:2642-2650.

Moate, P. J., W. Chalupa, R. C. Boston, and I. J. Lean. 2007. Milk fatty acids. I. Variation in the concentration of individual fatty acids in bovine milk. J. Dairy Sci. 90:4730-4739.

Mosley, E. E., B. Shafii, P. J. Moate, and M. A. McGuire. 2006. Cis-9, trans-11 conjugated linoleic acid is synthesized directly from vaccenic acid in lactating dairy cattle. J. Nutr. 136:570575.

Noakes, M., P. J. Nestel, and P. M. Clifton. 1996. Modifying the fatty acid profile of dairy products through feedlot technology lowers plasma cholesterol of humans consuming the products. Am. J. Clin. Nutr. 63:42-46.

NRC (National Research Council). 2001. Nutrient Requirements of Dairy Cattle, 7th Rev. Ed. National Academy Press, Washington DC, USA.

Ørskov, E. R. and I. McDonald. 1979. The estimation of protein degradability in the rumen from incubation measurements weighed according to rate passage. J. Agric. Sci. 92:499-503.

Ostrowska, E., F. R. Dunshea, M. Muralitharan, and R. F. Cross. 2000. Comparison of Silverion high performance liquid chromatographic quantification of free and methylated conjugated linoleic acid. Lipids 35:1147-1153.
Petit, H. V. and C. Côrtes. 2010. Milk production and composition, milk fatty acid profile, and blood composition of dairy cows fed whole or ground flaxseed in the first half of lactation. Anim. Feed Sci. Technol. 158:36-43.

Puppel, K., B. Kuczyńska, T. Nałęcz-Tarwacka, and H. Grodzki. 2013. Influence of linseed variety on fatty acid profile in cow's milk. J. Sci. Food Agric. 93:2276-2280.

SAS (Statistical Analysis System). 1996. SAS User' Guide: Statistics. SAS Institute Inc., Cary, NC, USA.

Shingfield, K. J., Y. Chilliard, V. Toivonen, P. Kairenius, and D. I. Givens. 2008. Trans fatty acids and bioactive lipids in ruminant milk. In: Bioactive Components of Milk. SpringerVerlag Berlin, Berlin, Germany. pp. 606:3-65.

Shingfield, K. J., M. R. F. Lee, D. J. Humphries, N. D. Scollan, V. Toivonen, D. E. Beever, and C. K. Reynolds. 2011. Effect of linseed oil and fish oil alone or as an equal mixture on ruminal fatty acid metabolism in growing steers fed maize silage-based diets. J. Anim. Sci. 89:3728-3741.

Steel, R. G. D. and J. H. Torrie. 1980. Principles and Procedures of Statistics: a biometeric approach, 2nd ed. McGrowhill, New York, USA.

Tudisco R., M. I. Cutrignelli, S. Calabrò, G. Piccolo, F. Bovera, A. Guglielmelli, G. Moniello, and F. Infascelli. 2010. Influence of organic systems on milk fatty acid profile and CLA in goats. Small Rumin. Res. 88:151-155.

Van Soest, P. J., J. B. Robertson, and B. A. Lewis. 1991. Methods for dietary fiber, neutral detergent fiber and non-starch polysaccharides in relation to animal production. J. Dairy Sci. 74:3583-3597.

Weisbjerg, M. R., M. K. Larsen, L. Hymøller, M. Thorhauge, U. Kidmose, J. H. Nielsen, and J. B. Andersen. 2013. Milk production and composition in Danish Holstein, Danish Red, and Danish Jersey cows supplemented with saturated or unsaturated fat. Livest. Sci. 155:60-70.

WHO (World Health Organization). 2003. Diet, Nutrition and the Prevention of Chronic Diseases, WHO technical report, Geneva. 